\title{
MANAGEMENT OF FOREIGN DIRECT INVESTMENT IN TERMS OF ITS REGIONAL LOCALIZATION IN SLOVAKIA
}

\author{
Rastislav Kotulič ${ }^{1}$, Peter Adamišin ${ }^{2}$, Ivana Kravčáková Vozárováa ${ }^{3}$
}

\begin{abstract}
The phenomenon of globalization had resulted in strengthening of the international capital movement in the 1990s, which led to an intensive retraction of small and open economies into the globalization process. The foreign direct investment (FDI) has since gained its importance, especially in the area of local and regional development. Its positive impact is reflected at the local, as well as at the national level. FDI is the means of ensuring technology transfer, increasing employment, as well as improving the quality of the workforce.

The aim of this article is to assess the stock of foreign direct investment and its localization in the Slovak regions at NUTS III level. From the content perspective, the article analyzes the economic development of the Slovak region by region, based on the stock of FDI, by using models from neoclassical theory of regional development for the period from 1999 to 2009 . We assumed that the different regional stock of foreign direct investment would have a significant impact on the economic differentiation of the regions in the Slovak Republic. This analysis confirmed our assumption.
\end{abstract}

JEL Classification Numbers: F21, R15, R58, DOI: http://dx.doi.org/10.12955/cbup.v2.444

Keywords: foreign direct investment, FDI, economic growth, NUTS III region, Slovakia

\section{Introduction}

The international capital movement has the same drivers as the movement of capital within the local economy or economic region. Attracting foreign investors to invest their capital in our market is no easy matter and requires the fulfillment of positive reviews for the six basic criteria, i.e. economic strength, business ethics, the degree of integration into the world economy, respect for rights, investment climate, and political stability.

The foreign investors consider the relationship of the current account deficit to gross domestic product of the country as an important indicator of economic stability. They also seek to have either domestic (local) market or the global market share. In the former case, the exports are minimal and the foreign enterprise competes only in the domestic market. It would probably end up creating a monopoly, which has known disadvantages for the economy of the host country. In the latter case, the exports are maximal and the foreign enterprise competes with other companies in the global market, which usually leads to the fact that the foreign enterprise expands production and invests in new technologies and innovations, resulting in a higher quality of goods and services (Kadeřábková, 2000).

\section{Literature Review}

Neoclassical theory of regional development is based on the idea that occurrence of state of deficiency in the economy generates the price differences, which create opportunities for profitable trade or for increasing the useful grouping of the production factors, and, thereby, attract the investments.

In an effort to use these options, the economic subjects react to price differences until the price differences and the states of deficiency are equalized again. This mechanism, in finding a balance, so spontaneously aligns inequalities. Taking into account the regional dimension, we can integrate regional-economic context into the general equilibrium models in several ways. If we follow the development of a one closed region, we will get to the basic model of neoclassical theory of regional growth based on capital accumulation process, in which savings and investment gather the capital, and the quantity of production of goods and services is growing. The dynamics of accumulation gradually

\footnotetext{
${ }^{1}$ Rastislav Kotulič, University of Prešov in Prešov, Slovakia, rastislav.kotulic@unipo.sk

${ }^{2}$ Peter Adamišin, University of Prešov in Prešov, Slovakia, peter.adamisin@unipo.sk

${ }^{3}$ Ivana Kravčáková Vozárová, University of Prešov in Prešov, Slovakia, ivana.vozarova@smail.unipo.sk
} 
declines and at the certain point, when the investments are able only to replace depreciations, there is stagnation of the accumulation.

After the extension of the neoclassical model of regional growth in opportunity for the free flow of production factors between regions, we can come to further conclusions that tend to support a balancing (convergence). The value of marginal product of production factors determines their prices (wage, interest, and annuity). By mobile production factors, neoclassical theory assumes that labor and capital are completely mobile and tends to lead to their transfer from the region, which would have been better with them staying within the region due to a relative shortage. If the production factor in the region is in short supply, then it is valued in accordance with the value of marginal product, which is higher than in other regions. It produces a net inflow of scarce production factor and the shortage is gradually eliminated. This process causes leveling out of the differences in the capital stock of the region and in reward. If this effect is combined with the aforementioned process of accumulation, the region with insufficient capital is growing even faster. If the relationships between regions would be reduced to exchange of goods, it would create different amenities between regions to specialization in the production of those goods, for which the region is better equipped. Due to the fact that each region uses its comparative advantages, the whole economy is able to produce more from the existing resources. The trade would be beneficial to all the regions involved. Thus, the importance of the theory for regional economic policy lies in the fact that if the prerequisites of the neoclassical model are fulfilled, then the economy will lead to a balanced development even without any political or economic interventions.

The role of regional economic policy should be to ensure the validity of neoclassical assumptions, thus increasing mobility of the labor and capital, eliminating the administrative restrictions in access to the regional markets, creating the conditions for better mobility of goods and services, and improving the flow of information between the regions and the completion of the infrastructure networks. The implementation of the instruments of the regional economic policy beyond the ensuring of assumptions would be counterproductive and would lead to distortions of optimal development, which would result in the loss of welfare (Maier \& Tödtling, 1997; Maier \& Tödtling, 1998).

The Slovak Republic can be characterized with a small and open economy. Not only is the development of the Slovak economy significantly reflected by any global development, but it is also reflected as an economy open to international capital movements, both in the forms of foreign direct investment (FDI) and of foreign portfolio investment (FPI).

The phenomenon of globalization had resulted in strengthening of the international capital movement back in the 1990s, which led to an intensive retraction of small and open economies into the globalization process. In the current economy, there are two best known theoretical models that explain the flow of the foreign investments. The first is the "gravity model," which emphasizes that the flow of investments is positively influenced by market size and negatively by the distance from the host country. The second model is called "agglomeration model of the economy," which emphasizes the fact that international companies tend to invest their capital in the same place (or in the same region) as their competitors, creating a so-called "synergistic effect" (Kotulič, 2006).

The foreign direct investment has since gained its importance, especially in the area of local and regional development. Its positive impact is reflected at the local, as well as at the national level. FDI is the means of ensuring technology transfer, increasing employment, as well as improving the quality of the workforce. For the regions, the foreign direct investment is very important. Currently, due to increasing fear of losing investors, the term "after care" is given into the foreground, which represents a kind of care for the investors operating in the region. Among the most important tools for the care of the investor are: the support of the cooperation with local or regional firms and an increasing of subcontracts; research and development support; the assistance in resolving of the administrative 
problems; an increasing comfort of the investors in the social sphere; the assistance in the human resource development; and the support in expanding of the production capacity (Ježek \& Ježková, 2011).

The foreign direct investment can be differentiated on the basis of entry into the country. Very attractive entry for the investor is "Green Field," in which the investor builds factory on the landalong with it are many associated economic benefits, such as tax breaks, provided by the economic policy of the domestic country. In the case of "Brown Field," the investor buys an existing enterprise that meets certain requirements, such production capacity and technological advancement. The investor can use the existing technology or introduce a new one with the possibility of increasing capacity and subsequent expansion. Another popular method of entry is "Joint Venture," in which a domestic company, with its local expertise and asset, and a foreign company, with its capital strength and advanced technology, join together in order to maximize capability and profit, through which they may also cover potential losses. Among the other methods are acquisitions, mergers, and various kinds of management and licensing agreements (Hečková \& Chapčáková, 2010).

The economic policy in many countries, including Slovakia, is inclined to actively attract investors through the investment incentives. Although international agreements in the principle do not allow discrimination of the foreign or domestic investors, the difference in treatment is evident in the criteria in which an investor must meet in order to get these incentives. The Slovak Republic is dominated by small and medium-sized enterprises (SMEs), which often cannot meet the criterion for minimum amount of investment, while foreign investors are more capitally equipped and often benefit from the investment incentives (Kincl, 2003).

As many advocates of foreign direct investments pointed out, some major benefits, mainly positive, associated with these incentives include job creation, or spillover effects, as well as improving the business environment. There are those in opposition, who express their negative attitude toward the provision of incentives, particular with increasing entitlements posed on public finances and the burdening public budgets. They also criticized the government negatively for the incentives and the fact that they discriminate against domestic entrepreneurs from receiving these incentives because they are honestly unable to cover the initial investment, which is determined by law (Karpat, 2010).

Many hitherto evaluated dimensions of the development or growth started to be in the recent period refilled by also environmental aspect and sphere of the sustainable development (Huttmanová \& Synčáková, 2009).

\section{Data and Methodology}

The aim of this article is to assess the value of foreign direct investment and its localization in the Slovak regions at NUTS III level. From the content perspective, the article analyzes the economic development of the Slovak region by region based on the value of foreign direct investment (FDI) by using models based on neoclassical theory of regional development for the period from 1999 to 2009. For evaluation of the economic level of the regions, their backwardness was used as the complex indicator of development in the form of foreign direct investment flowing into the region at NUTS III level (the regions of the Slovak Republic). Most backward of the Slovak regions were those whose percentage of the foreign direct investment, throughout the all period under review, was the lowest. The score, ranging from 0 to 100 points, represents the average of percentages of the stake of foreign direct investment over the period of 11 years, whereas the most points represent the most advanced level of the region and the fewest points represent the most backward level of the region. In the evaluation process, the standard mathematical and statistical relationships were used, along with numerical calculations. The statistical analysis was conducted using the software STATISTICA 10. 
The data used in the analysis were obtained from the official sources of National Bank of Slovakia (NBS) for the period of 1999 to 2009.

\section{Results and Discussion}

According to data of the National Bank of Slovakia, the highest value of foreign direct investment was mainly from these European Union countries, in the following order: the Netherlands, Austria, Germany, Italy, Czech Republic, Hungary, France, Belgium, and Luxembourg. Among the world's largest investors are companies that come mainly from the United States through companies located mainly in the Netherlands; these companies include U.S. Steel, Dell, Whirlpool, IBM, HP, and Johnson Controls. Companies from Germany include Siemens, Volkswagen, T-Systems; those from France include PSA Peugeot Citroen, and Alcatel. Furthermore, there are companies from Asia as well, such as Yazaki, Tisui Sumitomo, Sony, Panasonic, Samsung, Kia Motors, Hyundai Mobis, etc. (Rottiersová, 2013).

The flows of foreign direct investment into Slovak economy vary among its sectors. On the one hand, there are sectors in which the flow of foreign investment is relatively strong (e.g. industrial production, wholesale and retail trade, finance and insurance, and transport and storage). On the other hand, there are also industries in which the share of the foreign investor is negligible (e.g. agriculture, mining of raw materials, construction, hotels and restaurants, health and social care, etc.). The largest value of stock of the foreign direct investments was recorded in the services and industrial production. Table 1 summarizes the FDI value (in millions of USD) flowing into the different regions of the Slovak Republic.

\begin{tabular}{|c|c|c|c|c|c|c|c|c|c|c|c|}
\hline Name / Year & 1999 & 2000 & \begin{tabular}{|l|}
2001 \\
\end{tabular} & 2002 & 2003 & 2004 & 2005 & 2006 & 2007 & 2008 & 2009 \\
\hline Slovakia & 2272 & 3738 & 4836 & 7872 & 10580 & 21876 & 23656 & 33613 & 42695 & 51034 & 52537 \\
\hline $\begin{array}{c}\text { Bratislava } \\
\text { region (BA) }\end{array}$ & 1351 & 2091 & 3022 & 5612 & 7444 & 14298 & 13670 & 21105 & 26319 & 33640 & 34819 \\
\hline $\begin{array}{c}\text { Trnava } \\
\text { region }(\mathrm{TT})\end{array}$ & 202 & 204 & 239 & 338 & 534 & 1968 & 4192 & 3694 & 4350 & 4580 & 4955 \\
\hline $\begin{array}{c}\text { Trenčín } \\
\text { region (TN) }\end{array}$ & 153 & 142 & 147 & 228 & 363 & 1011 & 1076 & 1397 & 2059 & 2294 & 2499 \\
\hline $\begin{array}{l}\text { Nitra region } \\
\text { (NR) }\end{array}$ & 86 & 95 & 157 & 215 & 324 & 650 & 637 & 1350 & 1712 & 1971 & 2114 \\
\hline $\begin{array}{l}\text { Žilina region } \\
(\mathrm{ZA})\end{array}$ & 80 & 180 & 213 & 306 & 429 & 993 & 1218 & 1888 & 2927 & 3093 & 2995 \\
\hline $\begin{array}{c}\text { Banská } \\
\text { Bystrica } \\
\text { region }(\mathrm{BB})\end{array}$ & 113 & 115 & 169 & 208 & 270 & 532 & 483 & 685 & 1111 & 1235 & 1284 \\
\hline $\begin{array}{c}\text { Prešov } \\
\text { region (PO) }\end{array}$ & 100 & 100 & 114 & 147 & 182 & 314 & 282 & 324 & 328 & 513 & 612 \\
\hline $\begin{array}{c}\text { Košice } \\
\text { region (KE) }\end{array}$ & 187 & 811 & 776 & 819 & 1036 & 2110 & 2098 & 3169 & 3889 & 3709 & 3259 \\
\hline
\end{tabular}



Figure 1: Average share percentage of total FDI as level of regional development of Slovak regions
at NUTS III level

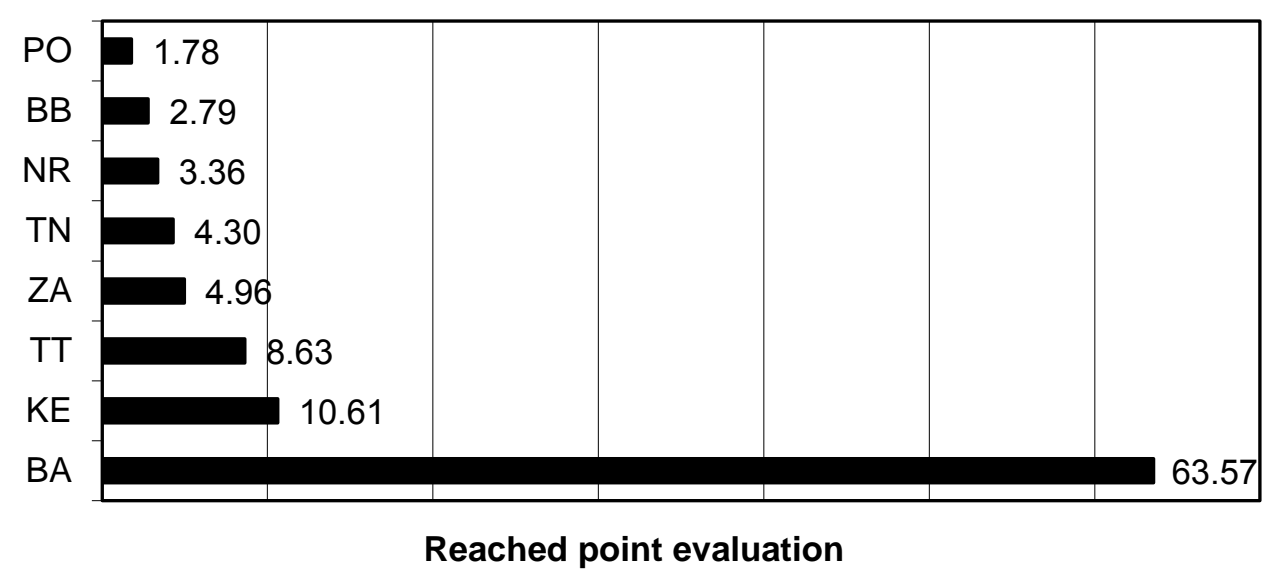

Source: Authors

The regions of the Slovak Republic are listed in Figure 1 based on their level of regional development scores - calculated using a set of methodology. The score ranging from 0 to 100 points is the average of the percentages of the share of foreign direct investment for the period of 11 years (from 1999 to 2009). Ranking first is Bratislava region (the center of the region is the capital of Slovakia Bratislava), which reached an average of $63.57 \%$ of the total foreign direct investments, over a sixyear period. In the second place is Košice region, which reached an average of $0.61 \%$ of total FDI. In the third place is Trnava region, which held an average of only $8.63 \%$ of total FDI. Furthermore, Žilina region ranked fourth at 4.96\%; Trenčín region ranked fifth at 4.30\%; Nitra region ranked sixth at 3.36\%; Banská Bystrica region ranked seventh at 2.79\%; and Prešov region ranked eighth with an average share of only $1.78 \%$ of total foreign direct investment.

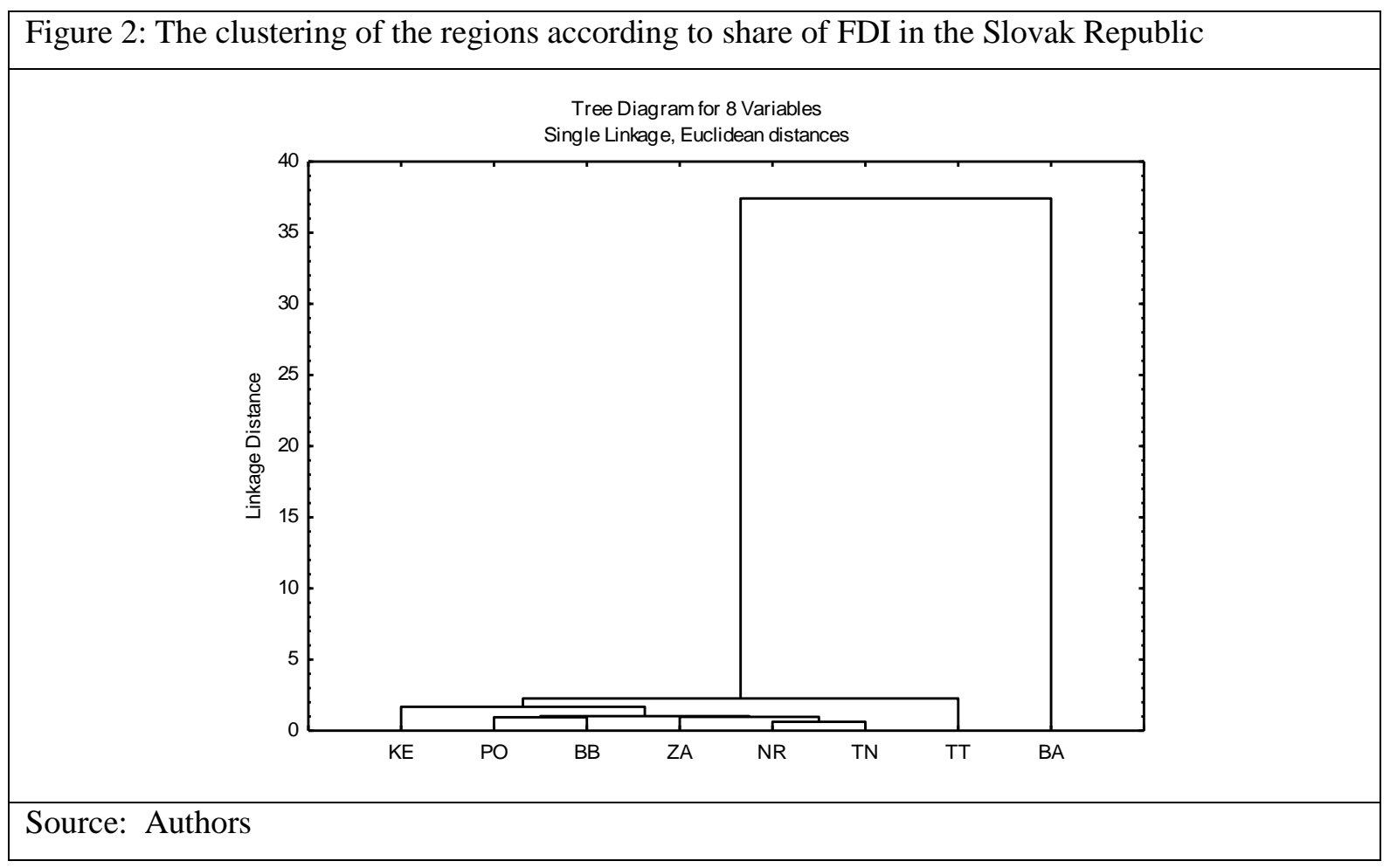


It should be noted, however, that significant differences in the volume of FDI was reflected in methodology used for their calculation, which referred to the inflow of foreign direct investments on the basis of place of business. Therefore, Bratislava had "officially" reached a significantly higher volume of the foreign direct investment. The regional divergence is represented on the dendrogram of clustering of the regions according to monitored parameter. Figure 2 illustrates clustering diagram for the regions, according to share of FDI in the Slovak Republic.

From the data analyzed, it can be observed that there exist some trends in regional development of Slovakia at level NUTS III (region) as follows:

- deepening of the differences in the level of FDI between regions with a high proportion of FDI and regions with a very low proportion of FDI, due to the so-called "agglomerate model of the economy,"

- rising trend in the level of FDI in regions with gradually increasing infrastructure.

\section{Conclusion}

Through an assessment of the state of foreign direct investment, on the basis of cluster analysis, it was possible to point that the Bratislava region had a strong dominance during the period of analysis. This dominant position of the Bratislava region is consistent with the classical theories of regional development, especially with regards to the theory of central cities (from W. Christaller), which was followed by J. Friedmann with the theory of polarized development, wherein the economic growth of a country can be strengthened by hierarchical system of cities and their functional regions. The strengthening of the hierarchical system of cities, however, inevitably leads to selection of centers of growth; this fact does not guarantee achieving the desired convergence (Sloboda, 2006; Blažek, 1993; Blažek \& Uhlíř, 2002; Maier \& Tödtling, 1998; Kotulič, Adamišin, \& Vozárová, 2013).

The decision on the location of investments is based primarily on its effectiveness, compared with other competing locations. The tendency for concentration of foreign direct investment in the most advanced regions is not only a problem in the Slovak Republic, but also in other countries of the European Union (Kotulič, 2006; Kotulič \& Adamišin, 2012; Dubravská, 2011). In spite of the declared effort to propagate more investment into less developed regions of Slovakia, implemented steps were inadequate and barely lessened the growing regional disparities. A significant part of the investments came without help from the state; these investments were directed mainly into Bratislava and Western Slovakia, which was confirmed to be the inflow of FDI by official figures of the National Bank of Slovakia.

The main reasons for low FDI inflow into an economy are generally due to insufficient political stability, poor law enforcement, unclear property rights relations, low attractiveness of the business environment, and incomplete process of transformation. Apparently, the volume of the foreign direct investment reflects the aforementioned drawbacks of the Slovak economy, and thus still does not meet the required level, which would speed up the transformation process of the microeconomic sphere and create more efficient growth for the Slovak economy.

Even in the $21^{\text {st }}$ century, the backward regions do face many challenges. Low income leads to low savings; low savings slow down capital growth; lack of the capital prevents the introduction of new machinery and rapid productivity growth; the low productivity circles back to the low income. How to break this vicious circle is a question that will require serious consideration even in this century. One way is to create the conditions for the entry of foreign capital (new technology and know-how) in the form of foreign direct investment, thus accelerating the process of convergence of the backward regions toward advanced level. 


\section{Acknowledgment}

This contribution was supported by the project VEGA 1/0541/11 and KEGA 032PU-4/2013.

\section{References}

Blažek, J. (1993). Regional development and regional policy: the main approaches in Western Europe. In L. Sykora (Ed.), Theoretical approaches in contemporary geography (pp. 120-146). Prague, Czech Republic: PrF UK Prague.

Blažek, J., \& Uhliř, D. (2002). Regional Development Theory: Outline, criticism, classification. Prague, Czech Republic: Karolinum.

Dubravská, M. (2011). Inflow of the Foreign Direct Investments to the Slovak Republic in the Years 1999 - 2008. In R. Kotulič (Ed.), Zborník vedeckých prác katedry ekonómie a ekonomiky ANNO 2011 [Scientific Proceedings of the Department of Economic Sciences and Economy ANNO 2011] (pp. 90-96). Presov, Slovakia: University of Presov in Presov.

Hečková, J., \& Chapčáková, A. (2010). The World Economy and International Economic Relations. Presov, Slovakia: University of Presov in Presov.

Huttmanová, E., \& Synčáková, L. (2009). Dimensions for evaluation of sustainable development and human development. In P. Jedlicka (Ed.), Hradec Economic Days 2009 (pp. 204-211). Hradec Kralove, Czech Republic: Gaudeamus.

Ježková, R., \& Ježek, J. (2011). Entrepreneurship and its municipal and regional support. Bratislava, Slovakia: EUROKÓDEX.

Kadebřáková, B. (2000). Economic growth and foreign direct investments. In Trends in Agricultural Economics and Management. Proceedings of the International Scientific Conference 2000 (pp. 315-323). Nitra, Slovakia: Slovak University of Agriculture in Nitra.

Karpat, A. (2011). The nature and importance of investment incentives. In Economic and Social development in Slovakia.

Proceedings of the International Scientific Conference. Bratislava, Slovakia: Institute of Economics and Management of Public Administration. Retrieved April 18, 2012 from http://crr.sk/data/files/zbornik2011.pdf

Kincl, M. (2003). Investment incentives as a form of state aid. Prague, Czech Republic: Linde Publishing, Ltd.

Kotulič, R. (2006). Foreign direct investment and their influence on economic growth and regional development. Review of Economic Perspectives, 4(2), 15-25.

Kotulič, R., \& Adamišin, P. (2012). The Economic Effects of Foreign Direct Investments Management on the Development of Slovak Regions. In V. Klímová, \& V. Žitek (Eds.), International Colloquium on Regional Sciences: 15. Proceedings of the contributions Valtice - 20-22 ${ }^{\text {nd }}$ June, 2012 (pp. 288-295). Brno, Czech Republic: Masaryk University in Brno.

Kotulič, R., Adamišin, P., \& Vozárová, I. (2013). Stock of foreign direct investment and its impact on sustainable development of the regions . In V. Klímová, \& V. Žitek (Eds.), International Colloquium on Regional Sciences. Proceedings of the contributions Valtice -19-21st June 2013 (pp. 162 - 167). Brno, Czech Republic: Masaryk University in Brno. doi:10.5817/CZ.MUNI.P210-6257-2013-19

Maier, G., \& Tödtling, F. (1997). Regional and Urban Economics. Bratislava, Slovakia: ELITA.

Maier, G., \& Tödtling, F. (1998). Regional and Urban Economics II. Bratislava, Slovakia: ELITA.

National Bank of Slovakia (2012). Foreign Direct Investment. Retrieved April 18, 2012 from http://www.nbs.sk/sk/statisticke-udaje/statistika-platobnej-bilancie/priame-zahranicne-investicie

Rottiersová, I. (2013). Foreign investments and their impact on regional development (Magister thesis). Presov, Slovakia: Faculty of Management of University of Presov in Presov.

Sloboda, D. (2006). Slovakia and regional disparities: theory, regions, indicators, methods. Retrieved April 18, 2012 from http://www3.ekf.tuke.sk/re/Disparity\%20a\%20perifernost/Regionalne\%20disparity/Slovensko_a_

regionalne_rozdiely.pdf 